\title{
Very long-term outcome after resection rectopexy for internal rectal intussusception
}

\author{
Durbeck Annichen ${ }^{\mathrm{a}, \mathrm{b}}$, Johannessen Hans-Olaf ${ }^{\mathrm{a}}$, Drolsum Anders ${ }^{\mathrm{c}}$, \\ Johnson Egil ${ }^{\mathrm{a}, \mathrm{d}}$
}

\author{
a Departments of Gastrointestinal- and Pediatric Surgery and ${ }^{\mathrm{c}}$ Radiology, Oslo \\ University Hospital, Ullevål, Oslo, Norway \\ ${ }^{b}$ Department of General Surgery, Diakonhjemmet Hospital, Oslo, Norway \\ ${ }^{\mathrm{d}}$ Institute of Clinical Medicine, University of Oslo, Oslo, Norway
}

Short title: Surgery rectal intussusception

Word count: 2877

Corresponding author

Egil Johnson

Department of Gastrointestinal- and Pediatric Surgery, Oslo University Hospital,

Ullevål, Norway, P. O. Box 4956 Nydalen, 0424 Oslo, Norway

phone: 4722119500

fax: $\quad 4722117470$

E-mail: egil.johnson@ulleval.no 


\begin{abstract}
Background: Both at short- and long-term follow-up we have reported major improvement of the symptom of constipation in patients treated with resection rectopexy for internal rectal intussusception (IRI). The aim was to study whether this improvement also persisted in a cohort of these patients after very long-term follow-up.
\end{abstract}

Methods: Observational and mainly prospective study of a cohort of 13 out of 48 patients with IRI who initially had ligament-preserving resection rectopexy with suture by laparoscopic $(n=11)$ or open $(n=2)$ technique. Outcome measures were morbidity, scores for constipation and anal incontinence, patients' report and HRQL.

Results: Thirteen out of the 48 initial patients (27\%) reported data at very longterm follow-up. Months from preoperatively to short-, long- and very long-term follow-up were median 6, 76 and 159, respectively. Corresponding mean (95\% CI) constipation scores were $11.5(8.3-14.7), 4.2(1.7-6.6)(\mathrm{p}<0.001), 5.3$ (3.6 - 7.0) $(\mathrm{p}<0.05)$ and $13.6(8.2-19.0)$. Number of constipated patients were (score $\geq 10$ ) were 8, 1, 0,1 and 9, respectively. Scores for anal incontinence were $6.1(2.4-11.4), 5.8(2.0$ - 9.5), $4.9(0.9$ - 9.0) and 7.9 (4.3-11.5), respectively. HRQL life was reduced for bodily pain, social functioning, mental health and general health perception. Percentage patients reporting symptomatic improvement were 100, 70 and 53, respectively.

Conclusions: Patients with IRI have a symptomatic relief for more than 6 years after resection rectopexy. The operation did not inflict permanent patient sequela. Motivated patients must be informed about very long-term deterioration of symptomatic relief.

Key words: IRI, resection rectopexy, constipation 


\section{Introduction}

Internal rectal intussusception (IRI), mainly occuring in women, is an invagination of the rectal wall that may also protrude into the anal canal. The diagnosis in straining patients is confirmed by anoscopy and defecography. Concomitant findings are rectocele, enterocele and sigmoidocele [1]. Substantial symptoms of defecatory disorders $[2,3]$ including incomplete evacuation of stool, pain and fecal incontinence [1, 4-8], is present in a minority of patients with demonstrable IRI.

In patients with overt rectal prolapse, faecal incontinence $[4,7,9,10]$ was usually improved after transabdominal rectopexy. However, constipation may be worsened $[4,7,8,10,11]$ and resection rectopexy with sigmoidal resection and preservation of the supportive lateral ligaments containing the neurovascular bundle, was introduced in order to avoid this adverse effect of treatment [12-14].

Several studies [15-18] using open or laparoscopic resection rectopexy for IRI, reported improvement in both anal incontinence and constipation in these patients. Mandatory for adequate evaluation of these patients is to identify constipation correctly [12, 13, 19-21], which has been improved by using linear discriminant analysis of 10 graded symptoms in the so-called KESS questionnaire (Knowles - Eccersley - Scott - Symptom questionnaire) [22]. We have reported [23] improvement in nine of the symptoms of the KESS score in 48 patients with IRI following ligament-preserving resection rectopexy both after short- and long-time follow-up of median half a year and 6 years, respectively.

The aim of this study was to evaluate outcome in a cohort of these patients, including HRQL, after very long follow up time of median 13 years.

\section{Materials and methods}

In the initial study [23] 48 patients with internal rectal intussusception (IRI) were from February 1999 to June 2006 treated with resection rectopexy with suture. The patients were evaluated preoperatively and postoperatively after short- and long-term follow-up of median 6 and 76 months, respectively. At very long follow-up in August 2018 eight patients were excluded (Fig. 1) based on journal 
data and phone interview, of whom one aged 78 received a sigmoidostomy after two years because of persisting obstructed defecation. The remaining 40 patients who initially wanted to participate were sent questionnaires concerning constipation, anal incontinence and health-related quality of life (HRQoL). Twenty seven patients were further excluded (Fig. 1). Four of the patients chose not to participate because of an intractable health problem owing to recent heart infarction, debilitating rheumatoid arthritis, bed ridden from amyotrophic lateral sclerosis and other abdominal complaints, respectively. Accordingly, remaining 13 patients were included in this study of short-, long- and very long-term follow-up, of whom three patients had chronic fatigue syndrome, metastatic breast cancer and heart failure, respectively. A prerequisite for being considered for surgery was heavy clinical symptoms (constipation and/or anal incontinence), refractory to conservative treatment, and demonstration of IRI both by defecography and anoscopy. Initially there was a full wall circular intussusception more than $3 \mathrm{~mm}$ thick reported to be symptomatic [24]. Four of the patients $(31 \%)$ had had hysterectomy for benign reasons, including one case of dilation for spastic anus.

Ligament preserving rectopexy [25] with suture and sigmoid resection was performed as described [16]. Briefly, rectum was mobilised posteriorly in the mesorectal plane to the tip of coccyx. Anteriorly the dissection was kept close to the rectal wall to the junction of the upper and middle third of vagina or to the seminal vesicles, preserving most of the lateral ligaments. The mesorectum was fixed loosely in the midline posteriorly with usually two absorbable sutures to the presacral fascia $2-4 \mathrm{~cm}$ below the promontory. It aimed at avoiding tension on the rectum, which followed the sacral curve. Redundant sigmoid was resected and the end-to-end anastomosis was stapled in the laparoscopically-assisted operations ( $\mathrm{n}=11)$ and hand sewn with continuous seromuscular suture in the open operations $(n=2)$, respectively.

At very long-term follow-up the patients were evaluated by self-reporting outcome by filling out questionnaires that were returned to the hospital. Symptoms and the patients' report on outcome of treatment were recorded. Fecal incontinence was assessed by St. Marks score [26]. Perfect continence to total incontinence are represented by a minimum score of 0 to a maximum score of 
24 points, respectively. From January 2001 the validated KESS score [22] was used, which contains 10 questions designed to define constipation. The total score was the sum of the scores for each question with a maximum possible score of 35 points. Using a cut off criterion of $\geq 10$ points, the KESS score discriminated between constipated patients and healthy controls with a sensitivity of 100\% (95\% confidence interval (CI) 95-100\%) and a specificity of $100 \%$ (63-100\%). At long-term follow-up patients were also asked about healthrelated quality of life (HRQoL). The patients had postoperative defecography at short-term follow-up, of whom 18 also volunteered at long-term follow-up.

HRQoL was assessed with the short form 36 (SF-36) (version 2) generic questionnaire consisting of 36 items. Thirty-five of these are grouped into the following eight health domains: (1) physical functioning, (2) social functioning, (3) role limitations due to physical problems, (4) role limitation due to emotional problems, (5) mental health, (6) vitality (energy and fatigue), (7) bodily pain and (8) general health perception. Each domain is graded on a scale of $0-100$, and the higher the score the better the HRQoL. The validity and reliability of the SF-36 form have been demonstrated for a number of countries including Norway (version 1) [27]. The data were compared with published norms from 2323 individuals in the general population. Although there are differences in the grading of some questions in version 2 versus version 1 of the SF-36 questionnaire for the four health dimensions $3,4,5$ and 6 , the mean values on a group level are comparable.

Fischer's exact test was used to compare within-group changes in the proportion of symptoms after operation. Wilcoxon matched paired signed rank test was used to compare score for each symptom between preoperatively and at long-term postoperatively. Overall constipation and incontinence scores from preoperatively and at short, long and very long-term postoperatively was measured by analysis of variance (ANOVA) with Bonferroni multiple comparisons test using the Instat for Windows ${ }^{\mathrm{TM}}$ statistics software package (GraphPad Software, San Diego, CA, USA). ANOVA was also used when measuring specific symptoms of Preoperatively and at short and long term postoperatively. Comparison of HRQoL between the patients and the background population was performed using unpaired t-test 
with Welch correction, based on the assumption that the populations have different standard deviations. Probabilities of less than 0.05 were considered significant.

The short-term follow-up of the patients was considered as routine clinical practice. The regional ethical committee south-east B (S-08098b) had no objections to the further follow-up of these patients who gave signed consent.

\section{Results}

\section{Patient material, treatment, morbidity and additional operations}

Characteristics of the patient material including, symptom duration, gender and lengths of short-, long- and very long-term follow up is depicted in Table 1. The cohort of 13 patients also evaluated at very long-term follow-up was initially operated from May 2001 to October 2005. Eleven patients (85\%) had planned laparoscopic resection rectopexy, of whom two of the operations were converted into open access because of adhesions and rectal perforation necessitating a temporary loop colostomy, respectively. Remaining two operations were planned for open access surgery. Additional morbidity postoperatively was a minor bleeding around a trocar and an anastomotic stenosis that was resolved by balloon dilation. Three patients later underwent anal dilation and operations for cystocele and haemorrhoids, respectively.

\section{Defecography}

The thirteen patients had had defecography at short-term follow-up of median 6 months (Table 2). The IRI was removed in 10 and reduced in three patients, respectively. Anterior rectocele, enterocele and sigmoidocele in two patients each were removed. One patient developed slight incontinence.

\section{Constipation}

Mean (95\% CI) KESS score preoperatively and at short-, long- and very longterm postoperatiely were $11.5(8.3-14.7), 4.2(1.7-6.6)(\mathrm{p}<0.001), 5.3(3.6-$ 7.0) $(\mathrm{p}<0.05)$ and $13.6(8.2-19.0)(\mathrm{p}>0,05)$, respectively. Eight patients were constipated (score $\geq 10$ ) preoperatively versus 1,0 and 9 patients at short-, longand very long-term follow-up, respectively. The specific scores for the 10 
different symptoms from preoperatively and at the different time points postoperatively are shown in Table 3 . Both at short- and long-term follow-up five symptoms were significantly reduced. The four symptoms bloating, minutes in lavatory per attempt, laxative use and painful evacuation effort were reduced at both time points. The fifth symptom that improved at short-term and longterm follow-up was incomplete evacuation of stool and unsuccessful evacuatory attempt, respectively. For unsuccessful evacuatory attempt, the proportion of patients with this symptom at long-term follow-up was significantly reduced $(\mathrm{p}=0.03)$, afflicting only one patient.

At very long-term follow-up, there was no significant improvement in any of the 10 symptoms of the KESS score. However, for incomplete evacuation of stool there both was a trend towards a persisting relief of this symptom $(\mathrm{p}=0.105)$ and a reduction in number of afflicted patients (13 vs 9).

One of the 13 patients examined, had a normal colonic transit time $(<4.2$ days).

\section{Incontinence}

Anal incontinence scores from preoperatively to short-, long- and very longterm follow-up were mean (95\% CI) 6.1 (2.4 - 11.4), 5.8 (2.0 - 9.5), 4.9 (0.9 $9.0)$ and $7.9(4.3-11.5)(\mathrm{p}=0.737)$, respectively. Corresponding number of patients with varying degree of anal incontinence (score $\geq 2)$ were $6(46 \%), 8$ (62\%), 7 (54\%) and 10 (77\%), respectively. Generally, from preoperatively to long- and very long-term follow-up, major anal incontinence was reduced, whilst a simultaneous increase of minor incontinence occurred as a consequence of operation (Table 4). With increasing age at long-term follow-up, there was a trend towards enhanced incontinence.

\section{Patients' report}

The percentage of patients who had an improved treatment result throughout the different times of follow-up declined from 100 to 80 and 54, respectively (Table 5). At last follow-up, three patients (23\%) also reported a deteriorated treatment result. However, $64 \%$ of the patients ultimately would have preferred to go through the same procedure. 


\section{Health-related quality of life}

HRQL data from very long-term follow-up for the 13 patients was compared with Norwegian general population within the same age bracket (Table 6). There was a significant deterioration in the patients for bodily pain, social functioning, mental health and general health perception in this group of patients as compared with the general population.

\section{Discussion}

In this cohort study of 13 out of initially 48 patients with IRI, who also was evaluated at very long follow-up of median 13 years since resection rectopexy, the main finding was that the improvement in symptoms of the KESS score demonstrated at short- (1/2 year) and long-term (6 years) follow-up no longer was present.

However, this conclusion needs further explanation for several reasons. First, because of a limited patient sample in this study (type 2 error), only five of the KESS score symptoms was improved at short- and long-term follow-up compared with nine of these symptoms in the initial study of 48 patients [23]. Second, although not significant, there still was a trend $(\mathrm{p}=0.105)$ towards reduction of the most dominating symptom incomplete evacuation of stool at long- at very long-term follow-up. Third, partial reasons for the patients' ultimate loss of symptom improvement may be influenced by deterioration of general somatic health from ageing and additional major comorbidity (metastatic breast cancer, heart failure, chronic fatigue syndrome). In addition, general reduction of mental health (Table 6) was more pronounced than at long-term follow-up of the total patient material [23]. Fourth, despite no persistent detectable symptomatic improvement, $53 \%$ of the patients felt better and as many as $64 \%$ would have said yes again to such an operation. This indicated that the subjective perception of the treatment result was better than actually reported for each symptom (Table 4). Fifth, the possibility of late recurrence of IRI must 
be considered. In this cohort only one patient had a defecography beyond shorttime follow-up, without demonstrating a recurrent prolapse 12 years after operation.

Anal incontinence scores remained mainly unaltered throughout the study (Table 4), although there was a trend towards more leakage, that probably mainly was age dependent and physiological as supported by a previous study in an ageand parity-matched control group of females without sphincter injury [28]. Since only one out of 48 patients ended up with a stoma, one interpretation may be that most patients in the long perspective also had an improved ability to evacuate stool (Table 3).

Stapled transanal rectal resection (STARR) for obstructed defecation because of symptomatic IRI reported comparable results after 6-20 months. However, in 45 patients the outcome deteriorated already from medium- (18 months) to long-term (42 months) follow-up based on symptom scores and constipation quality of life [29], to a level less satisfactorily than in this study for short- and long-time follow-up. To our knowledge this study for surgical treatment of IRI has the longest reported follow-up time [30]. However, for the past decade resection rectopexy with suture has to a large degree been replaced with a technique with ventral mesh rectopexy for both external rectal prolapse and internal rectal prolapse synonymous to IRI. A recent metaanalysis [31] reported patients with IRI of whom 1147 patients in 10 studies had ventral mesh rectopexy and 154 in 4 studies had resection rectopexy. Median (range) followup in months were $17(12-41)$ and $44.5(18-76)$, respectively. The weighted mean percentage of improvement of constipation ( $77 \%$ vs $69 \%$ ) and fecal incontinence (63\% vs $57 \%$ ) actually was quite similar, considering the longer follow-up time after resection rectopexy. Moreover, range for new-onset or worsening of constipation was from $0-11.5 \%$ and $2-5 \%$, respectively. Meanwhile, the results of longer follow-up after ventral mesh rectopexy is awaited, that will contribute to decide the more preferable treatment option. The postoperative complication rate for IRI was similar to studies using rectopexy with $[15,17,18]$ and without resection [32] and STARR [33, 34]. The patient with rectal perforation from a heat-induced injury of the ultracision instrument, necessitating a temporary colostomy, reported an excellent treatment result. 
None of the patients in this cohort reported delayed surgery as a consequence of complications from the initial resection rectopexy with suture. Mesh rectopexy is hampered with more long time complications because of a certain risk for mesh induced erosion into rectum and vagina, that require operation [35].

Patients with IRI and spastic pelvic floor syndrome should not be operated, since the chronic obstructed defecation is caused by lack of relaxation of the puborectal sling. These patients should receive biofeedback therapy for training in normal defecation [36]. In this situation, the intussusception is of minor significance for rectal emptying. Moreover, caution should be exerted against operation in patients with psychological aberrations, including anorexia nervosa.

The results support that motivated and bothered patients with IRI benefit from resection rectopexy. Before operation the patients foremost must be well informed about the time-dependent relapse of symptoms, in particular after more than 6 years of follow-up.

\section{Conclusion}

Following resection rectopexy for IRI the symptomatic improvement after half a year and 6 years, respectively, was not demonstrable at very long-term follow-up of 13 years. The procedure, however, did not cause any permanent sequela. The patients must be informed about the time-dependent loss of the effect of treatment. Operation is an option in well selected patients with excessive incomplete evacuation of stool and/or anal incontinence from dilation of the anal sphincters.

\section{Funding and conflict of interest}

There has been no funding of this project. The authors declare that they have no conflict of interest. 


\section{References}

1. Johansson C, Ihre T, Ahlbäck SO. Disturbances in the defecation mechanism with special reference to intussusception of the rectum (internal procidentia). Dis Colon Rectum 1985; 28: 920-924. doi:10.1007/bf02554307

2. Mellgren A, Bremmer S, Johansson C et al. Defecography. Results of investigations in 2,816 patients. Dis Colon Rectum 1994; 37: 1133-1141. doi:10.1007/bf02049817

3. Agachan F, Pfeifer J, Wexner SD. Defecography and proctography. Results of 744 patients. Dis Colon Rectum 1996; 39: 899-905. doi:10.1007/bf02053989

4. Graf W, Karlbom U, Påhlman L et al. Functional results after abdominal suture rectopexy for rectal prolapse or intussusception. Eur J Surg 1996; 162: 905-911

5. Ihre T. Internal procidentia of the rectum--treatment and results. Scand J Gastroenterol 1972; 7: 643646. doi:10.3109/00365527209180970

6. Ihre T, Seligson U. Intussusception of the rectum-internal procidentia: treatment and results in 90 patients. Dis Colon Rectum 1975; 18: 391-396. doi:10.1007/bf02587429

7. Schultz I, Mellgren A, Dolk A et al. Long-term results and functional outcome after Ripstein rectopexy. Dis Colon Rectum 2000; 43: 35-43. doi:10.1007/bf02237241

8. Schultz I, Mellgren A, Oberg M et al. Whole gut transit is prolonged after Ripstein rectopexy. Eur J Surg 1999; 165: 242-247. doi:10.1080/110241599750007117

9. Christiansen J, Zhu BW, Rasmussen OO et al. Internal rectal intussusception: results of surgical repair. Dis Colon Rectum 1992; 35: 1026-1028; discussion 1028-1029. doi:10.1007/bf02252991

10. Holmström B, Brodén G, Dolk A. Results of the Ripstein operation in the treatment of rectal prolapse and internal rectal procidentia. Dis Colon Rectum 1986; 29: 845-848. doi:10.1007/bf02555360

11. McCue JL, Thomson JP. Rectopexy for internal rectal intussusception. Br J Surg 1990; 77: 632-634. doi:10.1002/bjs.1800770613

12. Luukkonen P, Mikkonen U, Järvinen H. Abdominal rectopexy with sigmoidectomy vs. rectopexy alone for rectal prolapse: a prospective, randomized study. Int J Colorectal Dis 1992; 7: 219-222. doi:10.1007/bf00341225

13. McKee RF, Lauder JC, Poon FW et al. A prospective randomized study of abdominal rectopexy with and without sigmoidectomy in rectal prolapse. Surg Gynecol Obstet 1992; 174: 145-148

14. Johnson E, Stangeland A, Johannessen HO et al. Resection rectopexy for external rectal prolapse reduces constipation and anal incontinence. Scand J Surg 2007; 96: 56-61. doi:10.1177/145749690709600111

15. Kellokumpu IH, Vironen J, Scheinin T. Laparoscopic repair of rectal prolapse: a prospective study evaluating surgical outcome and changes in symptoms and bowel function. Surg Endosc 2000; 14: 634 640. doi:10.1007/s004640000017

16. Johnson E, Carlsen E, Mjåland $\mathrm{O}$ et al. Resection rectopexy for internal rectal intussusception reduces constipation and incomplete evacuation of stool. Eur J Surg Suppl 2003. 51-56

17. Tsiaoussis J, Chrysos E, Athanasakis E et al. Rectoanal intussusception: presentation of the disorder and late results of resection rectopexy. Dis Colon Rectum 2005; 48: 838-844. doi:10.1007/s10350-0040850-2

18. von Papen M, Ashari LH, Lumley JW et al. Functional results of laparoscopic resection rectopexy for symptomatic rectal intussusception. Dis Colon Rectum 2007; 50: 50-55. doi:10.1007/s10350-006-07811

19. Ashraf W, Park F, Lof J et al. An examination of the reliability of reported stool frequency in the diagnosis of idiopathic constipation. Am J Gastroenterol 1996; 91: 26-32

20. Karasick S, Ehrlich SM. Is constipation a disorder of defecation or impaired motility?: distinction based on defecography and colonic transit studies. AJR Am J Roentgenol 1996; 166: 63-66. doi:10.2214/ajr.166.1.8571906

21. Sarna SK. Physiology and pathophysiology of colonic motor activity (2). Dig Dis Sci 1991; 36: 9981018. doi:10.1007/bf01297155

22. Knowles CH, Eccersley AJ, Scott SM et al. Linear discriminant analysis of symptoms in patients with chronic constipation: validation of a new scoring system (KESS). Dis Colon Rectum 2000; 43: 14191426. doi:10.1007/bf02236639

23. Johnson E, Kjellevold K, Johannessen HO et al. Long-term outcome after resection rectopexy for internal rectal intussusception. ISRN gastroenterology 2012; 2012: 824671. doi:10.5402/2012/824671 
24. Dvorkin LS, Gladman MA, Epstein J et al. Rectal intussusception in symptomatic patients is different from that in asymptomatic volunteers. Br J Surg 2005; 92: 866-872. doi:10.1002/bjs.4912

25. Speakman CT, Madden MV, Nicholls RJ et al. Lateral ligament division during rectopexy causes constipation but prevents recurrence: results of a prospective randomized study. Br J Surg 1991; 78 : 1431-1433. doi:10.1002/bjs. 1800781207

26. Vaizey CJ, Carapeti E, Cahill JA et al. Prospective comparison of faecal incontinence grading systems. Gut 1999; 44: 77-80. doi:10.1136/gut.44.1.77

27. Loge JH, Kaasa S. Short form 36 (SF-36) health survey: normative data from the general Norwegian population. Scand J Soc Med 1998; 26: 250-258

28. Soerensen MM, Bek KM, Buntzen S et al. Long-term outcome of delayed primary or early secondary reconstruction of the anal sphincter after obstetrical injury. Dis Colon Rectum 2008; 51: 312-317. doi:10.1007/s10350-007-9084-4

29. Madbouly KM, Abbas KS, Hussein AM. Disappointing long-term outcomes after stapled transanal rectal resection for obstructed defecation. World J Surg 2010; 34: 2191-2196. doi:10.1007/s00268-0100638-6

30. Blaker K, Anandam JL. Functional Disorders: Rectoanal Intussusception. Clin Colon Rectal Surg 2017; 30: 5-11. doi:10.1055/s-0036-1593433

31. Emile SH, Elfeki HA, Youssef M et al. Abdominal rectopexy for the treatment of internal rectal prolapse: a systematic review and meta-analysis. Colorectal Dis 2017; 19: O13-o24. doi:10.1111/codi.13574

32. van Iersel JJ, Paulides TJ, Verheijen PM et al. Current status of laparoscopic and robotic ventral mesh rectopexy for external and internal rectal prolapse. World J Gastroenterol 2016; 22: 4977-4987. doi:10.3748/wjg.v22.i21.4977

33. Patel CB, Ragupathi M, Bhoot NH et al. Patient satisfaction and symptomatic outcomes following stapled transanal rectal resection for obstructed defecation syndrome. J Surg Res 2011; 165: e15-21. doi:10.1016/j.jss.2010.07.045

34. Goede AC, Glancy D, Carter H et al. Medium-term results of stapled transanal rectal resection (STARR) for obstructed defecation and symptomatic rectal-anal intussusception. Colorectal Dis 2011; 13: 1052-1057. doi:10.1111/j.1463-1318.2010.02405.x

35. Patil NS, Saluja SS, Mishra PK et al. Intrarectal migration of mesh following Rectopexy: Case series and review of literature. Int J Surg 2015; 20: 145-148. doi:10.1016/j.ijsu.2015.06.055

36. Camilleri M, Bharucha AE. Behavioural and new pharmacological treatments for constipation: getting the balance right. Gut 2010; 59: 1288-1296. doi:10.1136/gut.2009.199653 


\section{Tables}

Table 1. The patient material, including gender and age at very long-term follow up. Data are given as median and range, unless otherwise stated.

\begin{tabular}{|l|l|}
\hline Variable & \\
\hline $\begin{array}{l}\text { Years of symptoms before } \\
\text { treatment }\end{array}$ & $7(1-30)$ \\
\hline No of women & 13 \\
\hline $\begin{array}{c}\text { Age (years) } \\
\text { Short-term } \\
\text { Long-term }\end{array}$ & $74(57-84)$ \\
\hline Very long-term & $6(2-44)$ \\
\hline
\end{tabular}


Table 2. Defecography in the 13 patients preoperatively and short-term postoperatively. Figures are number of patients.

\begin{tabular}{|l|l|l|}
\hline Variable & Preoperatively & Postoperatively \\
\hline $\begin{array}{l}\text { Internal rectal } \\
\text { intussusception }\end{array}$ & 13 & 3 (reduced size) \\
\hline $\begin{array}{l}\text { Mucosal } \\
\text { prolapse }\end{array}$ & 0 & 0 \\
\hline Rectocele & 2 & 0 \\
\hline Enterocele & 2 & 0 \\
\hline Sigmoideocele & 2 & 0 \\
\hline $\begin{array}{l}\text { Reduced rectal } \\
\text { motility }\end{array}$ & 0 & 2 (temporary) \\
\hline Anismus & 0 & 0 \\
\hline $\begin{array}{l}\text { Slight } \\
\text { incontinence }\end{array}$ & 0 & 1 \\
\hline
\end{tabular}


Table 3. Number of afflicted patients and symptom severity score before and at different lengths of follow-up after resection rectopexy for IRI in 13 patients using the KESS score. The first line specifies the number of patients with each symptom. The score for each symptom is given as mean $(95 \% \mathrm{CI})$.

\begin{tabular}{|c|c|c|c|c|}
\hline \multirow{3}{*}{ Variable } & \multicolumn{4}{|c|}{ Number of patients Score } \\
\hline & \multirow[t]{2}{*}{ Preoperatively } & \multicolumn{3}{|l|}{ Postoperatively } \\
\hline & & Short-term & Long-term & Very Long-term \\
\hline $\begin{array}{l}\text { Feeling } \\
\text { incomplete } \\
\text { evacuation }\end{array}$ & $\begin{array}{l}13 \\
3.0(2.5 \text { to } 3.5)\end{array}$ & $\begin{array}{l}9 \\
1.2(0.5 \text { to } 1.8) \\
(\mathrm{p}<0.001) \\
\end{array}$ & $\begin{array}{l}11 \\
2.0(1.3 \text { to } 2.7)\end{array}$ & $9.2(1.1$ to 3.2$)$ \\
\hline Bloating & $\begin{array}{l}11 \\
1.5(0.9 \text { to } 2.2)\end{array}$ & $\begin{array}{l}6 \\
0.5(0.1 \text { to } 0.9) \\
(p<0.01)\end{array}$ & $\begin{array}{l}9 \\
0.8(0.4 \text { to } 1.10) \\
(\mathrm{p}<0.05) \\
\end{array}$ & $\begin{array}{l}12 \\
1.5(1.1 \text { to } 1.9)\end{array}$ \\
\hline $\begin{array}{l}\text { Minutes in } \\
\text { lavatory/attempt }\end{array}$ & $\begin{array}{l}8 \\
1.0(0.4 \text { to } 1.6)\end{array}$ & $\begin{array}{l}5 \\
0.5(0.1 \text { to } 0.9) \\
(\mathrm{p}<0.05)\end{array}$ & $\begin{array}{l}5 \\
0.4(0.1 \text { to } 0.7) \\
(p<0.05)\end{array}$ & $\begin{array}{l}8 \\
0.8(0.3 \text { to } 1.2)\end{array}$ \\
\hline Abdominal pain & $\begin{array}{l}8 \\
0.8(0.3 \text { to } 1.4)\end{array}$ & $\begin{array}{l}3 \\
0.5(-0.1 \text { to } \\
1.0)\end{array}$ & $\begin{array}{l}5 \\
0.4(0.1 \text { to } 0.7\end{array}$ & $\begin{array}{l}6 \\
0.9(0.2 \text { to } 1.6)\end{array}$ \\
\hline $\begin{array}{l}\text { Unsuccessful } \\
\text { evacuatory } \\
\text { attempts }\end{array}$ & $\begin{array}{l}7 \\
0.8(0.2 \text { to } 1.4)\end{array}$ & $\begin{array}{l}4 \\
0.4(0.0 \text { to } 0.8)\end{array}$ & $\begin{array}{l}1 \\
0.1(-0.0 \text { to } 0.2) \\
(p<0.05)\end{array}$ & $\begin{array}{l}9 \\
1.5(0.7 \text { to } 2.3)\end{array}$ \\
\hline Enemas/Digitation & $\begin{array}{l}7 \\
1.2(0.2 \text { to } 2.0)\end{array}$ & $\begin{array}{l}2 \\
0.2(0.0 \text { to } 0.4)\end{array}$ & $\begin{array}{l}4 \\
0.8(-0.1 \text { to } 1.7)\end{array}$ & $\begin{array}{l}6 \\
1.2(0.2 \text { to } 2.1)\end{array}$ \\
\hline Laxative use & $\begin{array}{l}7 \\
1.2(0.5 \text { to } 1.8)\end{array}$ & $\begin{array}{l}3 \\
0.3(-0.1 \text { to } 1.7) \\
(\mathrm{p}<0.01) \\
\end{array}$ & $\begin{array}{l}4 \\
0.4(0.0 \text { to } 0.9) \\
(p<0.05) \\
\end{array}$ & $\begin{array}{l}9 \\
1.4(0.8 \text { to } 2.0)\end{array}$ \\
\hline $\begin{array}{l}\text { Painful evacuation } \\
\text { effort }\end{array}$ & $\begin{array}{l}7 \\
0.7 \quad(0.2 \text { to } 1.2)\end{array}$ & \begin{tabular}{|l|}
2 \\
$0.2(-0.1$ to \\
$0.4)$ \\
$(p<0.05)$ \\
\end{tabular} & $\begin{array}{l}1 \\
0.1(-0.1 \text { to } 0.2) \\
(\mathrm{p}<0.05)\end{array}$ & $\begin{array}{l}6 \\
0.8(0.2 \text { to } 1.4)\end{array}$ \\
\hline Stool consistency & $\begin{array}{l}6 \\
1.10(0.3 \text { to } 1.9)\end{array}$ & $\begin{array}{l}4 \\
0.2(0.0 \text { to } 0.6)\end{array}$ & $\begin{array}{l}4 \\
0.5(0.0 \text { to } 0.9)\end{array}$ & $\begin{array}{l}9 \\
1.8(0.9 \text { to } 2.6)\end{array}$ \\
\hline $\begin{array}{l}\text { Frequency of } \\
\text { bowel movement }\end{array}$ & $\begin{array}{l}0 \\
\text { NPS }\end{array}$ & $\begin{array}{l}1 \\
0.1 \quad(-0.1 \text { to } \\
0.2)\end{array}$ & \begin{tabular}{|l|}
0 \\
NPS
\end{tabular} & $\begin{array}{l}1 \\
0.2(-0.2 \text { to } 0.5)\end{array}$ \\
\hline Total score & $11.5(8.3$ to 14.7$)$ & $4.2(1.7$ to 6.6$)$ & $5.3(3.6$ to 7.0$)$ & $13.6(8.4$ to 19.0$)$ \\
\hline
\end{tabular}

NPS=no positive score defining a symptom. The $\mathrm{p}$ values reveal significant reduction of symptoms as a consequence of IRI. 
Table 4. Symptoms of anal incontinence in the 13 patients preoperatively

(left), at short-term (middle), long-term (right) and at very long-term follow-up (very right).

The figures are number of patients.

\begin{tabular}{|l|l|l|l|l|l|}
\hline & Never & Rarely & Sometimes & Weekly & Daily \\
\hline $\begin{array}{l}\text { Incontinence } \\
\text { for solid } \\
\text { stool }\end{array}$ & $10 / 10 / 11 / 5$ & $0 / 1 / 0 / 0$ & $0 / 1 / 1 / 5$ & $2 / 0 / 0 / 1$ & $1 / 1 / 1 / 2$ \\
\hline $\begin{array}{l}\text { Incontinence } \\
\text { for liquid } \\
\text { stool }\end{array}$ & $8 / 7 / 9 / 4$ & $1 / 2 / 1 / 0$ & $0 / 1 / 1 / 6$ & $1 / 1 / 1 / 1$ & $3 / 2 / 1 / 2$ \\
\hline $\begin{array}{l}\text { Incontinence } \\
\text { for gas }\end{array}$ & $8 / 6 / 9 / 4$ & $0 / 1 / 1 / 2$ & $2 / 1 / 2 / 1$ & $0 / 2 / 0 / 1$ & $3 / 3 / 1 / 5$ \\
\hline $\begin{array}{l}\text { Alteration in } \\
\text { lifestyle }\end{array}$ & $8 / 9 / 7 / 4$ & $0 / 0 / 2 / 3$ & $2 / 1 / 1 / 2$ & $0 / 0 / 2 / 3$ & $3 / 3 / 1 / 1$ \\
\hline $\begin{array}{l}\text { Need to wear } \\
\text { a pad or plug }\end{array}$ & & & & Yes & \\
\hline $\begin{array}{l}\text { Taking } \\
\text { constipating } \\
\text { medicines }\end{array}$ & & & $6 / 4 / 4 / 1$ & \\
\hline $\begin{array}{l}\text { Able to delay } \\
\text { defecation } \\
\text { for 15 min }\end{array}$ & & & $0 / 1 / 2 / 3$ & \\
\hline
\end{tabular}

Rarely and sometimes mean one and two to three episode(s) of anal incontinence during 4 weeks, respectively. 
Table 5. Report of 13 patients concerning the treatment result at different times of follow. Figures are number of patients, percentages in parentheses.

\begin{tabular}{|l|l|l|l|}
\hline & Short-term & Long-term & Very long-term \\
\hline Excellent & 0 & $1(8)$ & $2(15)$ \\
\hline Improved & $13(100)$ & $8(62)$ & $5(38)$ \\
\hline Unaltered & 0 & $3(23)$ & $3(23)$ \\
\hline Worse & 0 & $1(8)$ & $2(15)$ \\
\hline Much worse & 0 & 0 & $1 \quad(8)$ \\
\hline
\end{tabular}


Table 6. HRQoL (SF-36) results for 13 patients operated for IRI at very long-term follow up compared with the general Norwegian population. Scores are given as mean (SD).

\begin{tabular}{|l|l|l|l|}
\hline $\begin{array}{l}\text { Health } \\
\text { dimension }\end{array}$ & $\begin{array}{l}\text { Patients } \\
(\mathrm{n}=13)\end{array}$ & $\begin{array}{l}\text { General } \\
\text { population } \\
(\mathrm{n}=2323)\end{array}$ & P value \\
\hline $\begin{array}{l}\text { Physical } \\
\text { functioning }\end{array}$ & $48.7(21.0)$ & $56.1(27.8)$ & 0.25 \\
\hline $\begin{array}{l}\text { Role limitation } \\
\text { due to physical } \\
\text { problems* }\end{array}$ & $54.1(25.1)$ & $37.0(43.0)$ & 0.27 \\
\hline $\begin{array}{l}\text { Role limitation } \\
\text { due to emotional } \\
\text { problems* }\end{array}$ & $63.1(27,1)$ & $59.5(44.2)$ & 0.68 \\
\hline Bodily pain & $40.6(23,6)$ & $59.5(29.0)$ & 0.01 \\
\hline $\begin{array}{l}\text { Social } \\
\text { functioning }\end{array}$ & $39.3(8.3)$ & $74.1(28.7)$ & $<0.0001$ \\
\hline Mental health* & $56.7(10.3)$ & $76.7(17.8)$ & $<0.0001$ \\
\hline Vitality* & $47.9(11,1)$ & $50.6(22,9)$ & 0.48 \\
\hline $\begin{array}{l}\text { General health } \\
\text { perception }\end{array}$ & $46.6(11.0)$ & $62.5(22.1)$ & 0.0003 \\
\hline
\end{tabular}

*Although there are subtle differences in the different versions of the SF-36 questionnaire concerning these four health dimensions, the data can be compared 


\section{Figure legend:}

Figure 1. Flow chart displaying reasons for exclusions from the study.

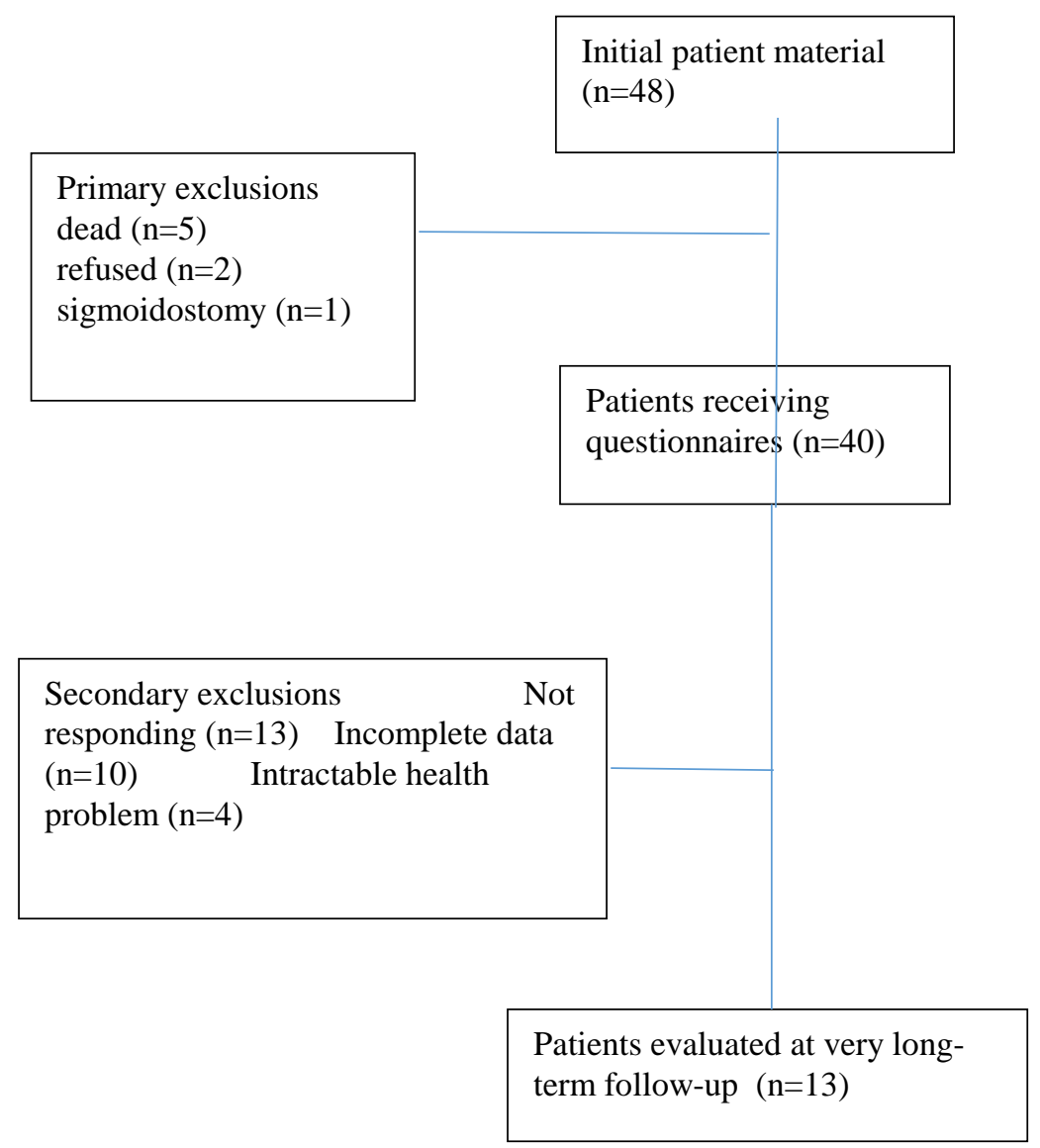

